\title{
THE PATTERN OF IMMUNE CELL INFILTRATION IN CHROMOBLASTOMYCOSIS: INVOLVEMENT OF MACROPHAGE INFLAMMATORY PROTEIN-1 ALPHA/CCL3 AND FUNGI PERSISTENCE
}

\author{
Vanuza Cristina SÁ(1), Tarcília Aparecida SILVA(2), Carmelia Matos Santiago REIS(3), Fernando Queiroz CUNHA(4), Florêncio FIGUEIREDO(5) \\ \& Anamélia Lorenzetti BOCCA(1)
}

\begin{abstract}
SUMMARY
Chromoblastomycosis $(\mathrm{CR})$ is a subcutaneous chronic mycosis characterized by a granulomatous inflammatory response. However, little is known regarding the pattern of leukocyte subsets in CR and the pathways involved in their recruitment. The objective of this study was to assess the cellular subsets, chemokine, chemokine receptors and enzymes in CR. The inflammatory infiltrate was characterized by immunohistochemistry using antibodies against macrophages (CD68), Langerhans'cells (S100), lymphocytes (CD3, CD4, CD8, CD45RO, CD20 and CD56) and neutrophils (CD15). The expression of MIP-1 $\alpha$ (Macrophage inflammatory protein-1 $\alpha$ ), chemokine receptors (CXCR3 and CCR1) and enzymes (superoxide dismutase-SOD and nitric oxide synthase-iNOS) was also evaluated by the same method. We observed an increase in all populations evaluated when compared with the controls. Numbers of $\mathrm{CD} 15^{+}$and $\mathrm{CD} 6^{+}$were significantly lower than $\mathrm{CD}^{+}, \mathrm{CD} 4^{+}, \mathrm{CD} 20^{+}$and $\mathrm{CD} 68^{+}$cells. Statistical analysis revealed an association of fungi numbers with CD3, CD45RO and iNOS-positive cells. Furthermore, MIP-1 $\alpha$ expression was associated with CD45RO, CD68, iNOS and CXCR3. Our results suggest a possible role of MIP-1 $\alpha$ and fungi persistence in the cell infiltration in $\mathrm{CR}$ sites.
\end{abstract}

KEYWORDS: Chromoblastomycosis; Granulomas; Chemokine.

\section{INTRODUCTION}

Chromoblastomycosis (CR) is a chronic skin infection caused by various members of the Dematiaceae family, including Fonsecaea pedrosoi, Phialophora verrucosa, Fonsecaea compactum, Cladosporium carrioni, Rinocladiella aquaspersa ${ }^{4-5,24}$.

Histopathologic findings of CR include pseudo-epitheliomatous epidermal hyperplasia, hyperkeratosis, irregular acanthosis, alternating with areas of atrophy and collection of inflammatory cells forming epidermic abscesses. At the dermal level, a granulomatous reaction with different grades of fibrosis ${ }^{7,26}$ can be observed. Fungi may be observed among these structures or, more frequently, in the interior of the giant cells, under the form of round hazel cells containing a distinct membrane ${ }^{7,26}$. Besides the presence of macrophages, $\mathrm{T}$ lymphocytes $\left(\mathrm{CD}^{+}\right.$and $\left.\mathrm{CD}^{+}\right)$, B lymphocytes, Langerhans' cells and epithelioid cells in the granulomas, a vast amount of polymorphonuclear (PMN) cells and eosinophils infiltrating in the lesion can be observed ${ }^{3,7,22,26}$. In this setting, expression of selective recruitors of these cell types, such as chemokines, have not been previously assessed in CR. Chemokine and chemokine receptors are responsible for the leukocyte recruitment and activation in different inflammatory diseases ${ }^{25,27}$ including fungal infections ${ }^{23}$. Chemokines are classified into four subfamilies according to the configuration of cysteine residues near the $\mathrm{N}$-terminal, depending on whether the first two cysteines are separated $(\mathrm{CXC}, \mathrm{CX} 3 \mathrm{C})$ or not $(\mathrm{CC}, \mathrm{C})$ by an intervening amino acid ${ }^{17}$ ${ }^{18}$. Of these, MIP-1 $\alpha$ (Macrophage inflammatory protein- $1 \alpha$, also designated CCL3) is a CC chemokine with potent chemotactic activity for various subsets of mononuclear leukocytes and also neutrophils ${ }^{13,15,17}$ $18,25,27$, playing an important role in cellular responses in fungal disease ${ }^{14,16}$. MIP- $1 \alpha$ is a ligand of CCR1, which is found on Th1 cells, monocytes, macrophages ${ }^{1,20-21}$ and neutrophils ${ }^{27}$. Conversely, CXCR3 is expressed preferentially on Th1 lymphocytes and at lower levels in Th2 cells, and its ligand comprises Mig, IP-10 and I-TAC ${ }^{1,20-21}$.

Although the distribution of immune cells has been previously reported in the $\mathrm{CR}$ granulomas ${ }^{3,22}$, the pathways associated with inflammatory cell recruitment at these sites are poorly understood. Therefore, in order to better characterize the lesions of CR and the cell-mediated immune reactivity, the present paper studied the populations of macrophages, lymphocytes, neutrophils and Langerhans'cells and their correlation with the expression of MIP- $1 \alpha$, CXCR3, CCR1, enzymes and the persistence of fungi in CR sites.

(1) Cell Biology Department, Institute of Biology, Universidade de Brasília, Brasília, Distrito Federal, Brazil.

(2) Department of Oral Surgery and Pathology, School of Dentistry, Universidade Federal de Minas Gerais, Belo Horizonte, Minas Gerais, Brazil.

(3) Laboratório de Micologia, Hospital Universitário de Brasília, Brasília, Distrito Federal, Brazil

(4) Department of Pharmacology, School of Medicine of Ribeirão Preto, Universidade de São Paulo, Ribeirão Preto, São Paulo, Brazil.

(5) Universidade Católica de Brasília, Brasília, Distrito Federal, Brazil.

Correspondence to: Tarcília Aparecida da Silva, Departamento de Cirurgia e Patologia, Faculdade de Odontologia, Universidade Federal de Minas Gerais, Av. Antônio Carlos 6627, 31.270901, Belo Horizonte, Minas Gerais, Brazil. Phone: 5531 3499-2476. E-mail: tarcilia@odonto.ufmg.br. 
SÁ, V.C.; SILVA, T.A.; REIS, C.M.S.; CUNHA, F.Q.; FIGUEIREDO, F. \& BOCCA, A.L. - The pattern of immune cell infiltration in chromoblastomycosis: involvement of macrophage inflammatory protein-1 alpha/CCL3 and fungi persistence. Rev. Inst. Med. trop. S. Paulo, 49(1): 49-53, 2007.

\section{MATERIALS AND METHODS}

Human subjects: Biopsies were obtained from 10 patients with clinical and histopathological diagnosis of CR before the beginning of treatment for diagnostic purposes. All samples were obtained under institutionally approved protocols of the School of Medicine Ethical Committee, University of Brasilia. The subjects of this study were 10 adult Brazilian patients with ages ranging from 52 to 73 years and with no history of drug use or positivity for HIV. All specimens were collected from foot and inferior limbs, the common clinical presentation was a verrucous plaque with slow growth and evolution varied from 10 to 30 years. The control group comprised two samples of clinically healthy skin of the face taken for esthetic purposes.

Tissue preparation: The samples were fixed in neutral buffered formalin, embedded by a routine technique in paraffin wax and sectioned at $5 \mu \mathrm{m}$ for hematoxylin and eosin, Grocott and immunohistochemical staining.

Immunohistochemistry: From the tissues embedded in paraffin wax, 5 - $\mu \mathrm{m}$ thick sections were cut and collected on gelatin-coated glass slides. Briefly, the samples were immersed in $3 \mathrm{mM}$ citrate buffer (pH 6.0) for 10 minutes at $120{ }^{\circ} \mathrm{C}$ for antigen retrieval. Subsequently, sections were incubated in $3 \%$ normal serum and then with one of the following: mouse anti-human CD3 monoclonal antibody (M7193; Dako, Glostrup, Denmark); mouse anti-human CD4 monoclonal antibody (M0716, Dako); mouse anti-human CD8 monoclonal antibody (M7103; Dako); mouse anti-human CD45RO monoclonal antibody (M0742; Dako), mouse anti-human CD20 monoclonal antibody (M0755; Dako), mouse anti-human CD68 monoclonal antibody (M0876; Dako), mouse anti-human CD56 monoclonal antibody (M07174; Dako), mouse anti-human CD15 monoclonal antibody (M7074; Dako), rabbit anti-human S100 polyclonal antibody (Z0311; Dako), rabbit anti-human iNOS polyclonal antibody (C-20; sc652, Santa Cruz Biotechnology, Santa Cruz, CA, USA), rabbit anti-human SOD polyclonal antibody (FL-154; sc11407, Santa Cruz), goat anti-human MIP-1 $\alpha$ polyclonal antibody (C-16; sc1381, Santa Cruz), goat antihuman CXCR3 polyclonal antibody (C-20; sc6226, Santa Cruz), goat anti-human CCR1 polyclonal antibody (C-20; sc6125, Santa Cruz). All antibodies were diluted in PBS-BSA at 1:100, except anti-S100, which was used at 1:500. After, the sections were incubated with appropriate biotinylated antibodies (Dako) for $20 \mathrm{~min}$. Sections were then incubated with avidin-biotin complex (Kit LSAB-HRP, Dako). After washing, the slides were counterstained with Mayer's hematoxylin. Negative controls were obtained by the omission of primary antibodies.

Cell counting and statistical analysis: The CR specimens were scored for the intensity of immunoexpression of each cell marker as follows: discrete, immunostaining similar or two times stronger than observed for control samples; moderate, immunostaining tree or four times more intense than control; intense, immunostaining five times more stronger than control. The number of muriform cells, identified by Grocott stain and of positively stained cells for each antibody were determined using an integration graticule (Carl Zeiss-4740680000000Netzmikrometer 12.5x). All cells were counted per five consecutive microscopic high power fields $(\mathrm{x} 400)$ and, in this magnification, each field (integration graticule) has area of $0.015625 \mathrm{~mm}^{2}$; thus a total area of $0.078125 \mathrm{~mm}^{2}$ was analyzed in each specimen. Results were expressed as the mean of positive cells \pm standard deviation (SD) of $n$ observations, per $\mathrm{mm}^{2}$. Data were analyzed using the Kruskal-Wallis test followed by Dunn's test. To examine the relationship between the fungi population, infiltrating cells, chemokine, chemokine receptors and enzymes, simple regression analysis was performed. All statistical tests were performed using the SPSS 10.0 software.

\section{RESULTS}

In the present study, by means of routine HE staining followed by Grocott staining, the main microscopic characteristics of CR were observed. A granulomatous inflammatory disease was characterized by the presence of aggregates of $\mathrm{T}$ and $\mathrm{B}$ lymphocytes (Fig. 1A, B, C, D, E and F), eosinophils, neutrophils (Fig. 1G) forming microabscess, and macrophages (Fig. 1H). Only discrete areas of fibrosis were detected in all samples. Muriform cells were identified scattered in the connective tissue or inside microabscesses as well as within giant cells, with routine HE and Grocott stain.

As observed in Figure 1I, S100 positive cells were mostly restricted to the cells in the epithelium basal layer. The SOD expression (Fig. $1 \mathrm{~N})$ varied from moderate $(11.1 \%)$ to intense ( $88 \%$ of cases). On the other hand, iNOS expression (Fig. 1M) varied from discrete (11.1\%) to moderate ( $88 \%$ of cases). The iNOS expression was mostly linked to macrophages and multinucleated giant cells, while SOD expression was found in neutrophils, macrophages and epithelial cells. CCR1 (Fig. 1J) and CXCR3 expression (Fig. 1K) were most detected on mononuclear cells. The expression of MIP-1 $\alpha$ (Fig. 1L) varied from moderate to intense and was linked to macrophages and multinucleated giant cells and also to the extracellular matrix. Controls exhibited negative expression for SOD (Fig. 1O) as well as for all analyzed markers (data not shown). No positive staining was observed when primary antibodies were omitted.

An increase in all cell populations analyzed was observed (Fig. 2A) when compared to the controls (Fig. 2B). A significantly high proportion of $\mathrm{CD}^{+}(p=0.0031), \mathrm{CD}^{+}(p=0.0404), \mathrm{CD} 20^{+}(p=0.012)$ and $\mathrm{CD} 68^{+}$ $(p=0.0023)$ were observed in relation to $\mathrm{CD} 15^{+}$. Furthermore, CD56 ${ }^{+}$ numbers were lower when compared to $\mathrm{CD}^{+}(p=0.0035), \mathrm{CD}^{+}(p=$ $0.0452), \mathrm{CD}_{2} 0^{+}(p=0.014)$ and $\mathrm{CD}^{+} 8^{+}(p=0.0057)$. The numbers of $\mathrm{CD}^{+} 8^{+}$were significantly higher than $\mathrm{CD}^{+}$cells $(p=0.043)$. No differences between other cell types were detected (Fig. 2).

Statistical regression analysis revealed a significant association of the fungal load with $\mathrm{CD}^{+}$and activated lymphocytes $\left(\mathrm{CD} 45 \mathrm{RO}^{+}\right)$and with iNOS positive cells. Furthermore, MIP- $1 \alpha$ expression was found to be associated with CD45RO, CD68, iNOS and CXCR3 immunolabeled cells (Table 1). No correlations were observed between cell markers and CCR1 (data not shown).

\section{DISCUSSION}

Our results showed increased numbers of all cell markers analyzed when compared to the healthy skin controls obtained from the face. High proportions of $\mathrm{CD}^{+}, \mathrm{CD}^{+}, \mathrm{CD} 20^{+}$and $\mathrm{CD} 68^{+}$cells in relation to other cells subsets, especially $\mathrm{CD} 15^{+}$and $\mathrm{CD} 56^{+}$, were also observed. In contrast to previous studies ${ }^{3}$, which detected a higher number of 


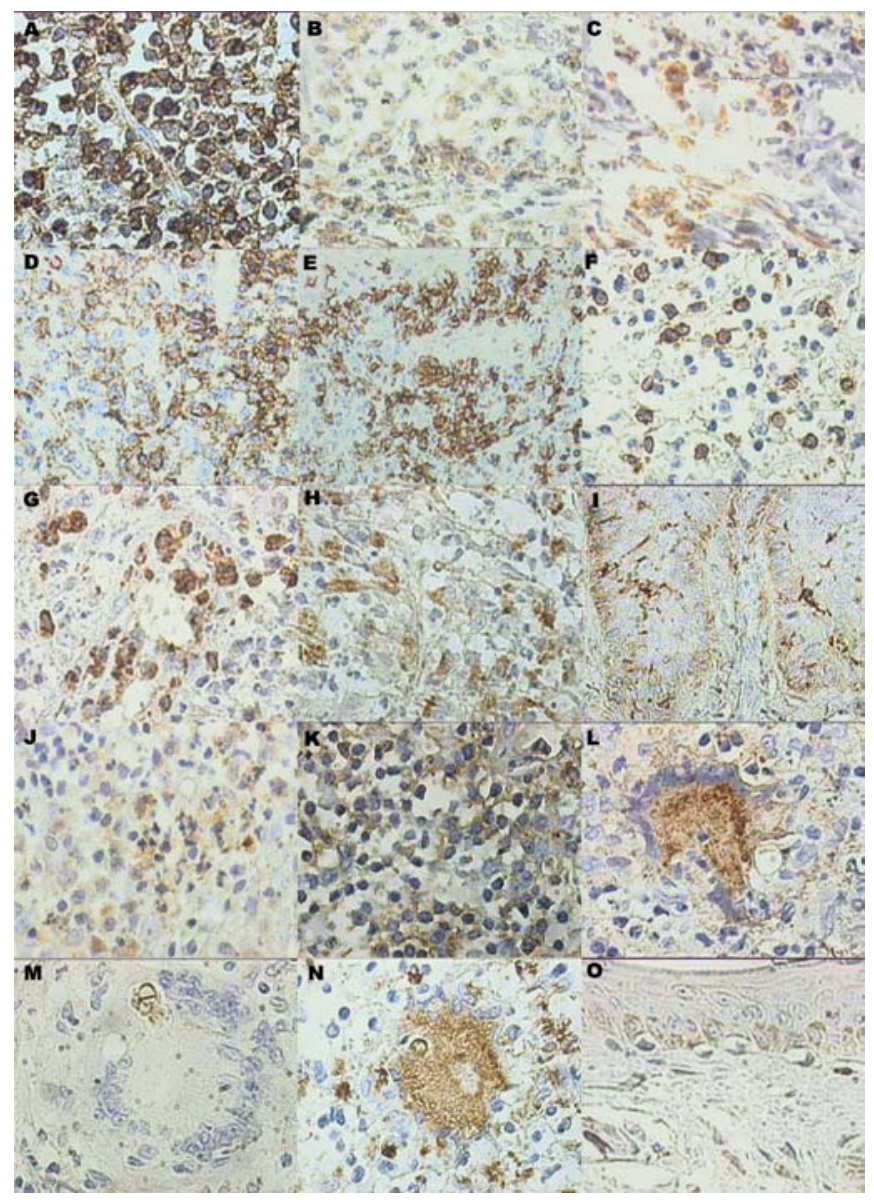

Fig. 1 - Immunohistochemical staining of (A) CD3 (x400), (B) CD4 (x200), (C) CD8 (x200) (D) CD45RO (x200), (E) CD20 (x200), (F) CD56 (x200), (G) CD15 (x200), (H) CD68 (x200), (I) S100 (x200), (J) CCR1 (x200), (K) CXCR3 (x400), (L) MIP-1a (x400), (M) iNOS $(x 400)$ and $(\mathrm{N})$ SOD $(x 400)$ positive cells in chromoblastomycosis lesions. (O) Negative control (x200) of healthy skin showing negative staining for SOD.
Table 1

Simple regression analysis of inflammatory cells, fungi population and MIP- $1 \alpha$ expression in chromoblastomycosis lesions

\begin{tabular}{lcccc}
\hline Cell markers & \multicolumn{2}{c}{ Fungi } & \multicolumn{2}{c}{ MIP-1 $\alpha$} \\
\hline CD3 & $p$ & $R$ square & $\mathrm{p}$ & $R$ square \\
CD4 & $\mathbf{0 . 0 9 *}$ & $\mathbf{0 . 8 4 9}$ & 0.151 & 0.440 \\
CD8 & 0.198 & 0.373 & 0.236 & 0.326 \\
CD45RO & 0.149 & 0.443 & 0.559 & 0.092 \\
C15 & $\mathbf{0 . 0 1 4} *$ & $\mathbf{0 . 8 1 2}$ & $\mathbf{0 . 0 5 5}$ & $\mathbf{0 . 6 4 4}$ \\
CD20 & 0.404 & 0.179 & 0.111 & 0.509 \\
CD56 & 0.220 & 0.588 & 0.485 & 0.128 \\
CD68 & 0.287 & 0.274 & 0.262 & 0.298 \\
iNOS & 0.554 & 0.094 & $\mathbf{0 . 0 4 6}$ & $\mathbf{0 . 6 7 0}$ \\
MIP- $\alpha$ & $\mathbf{0 . 0 0 7} *$ & $\mathbf{0 . 8 6 2}$ & $\mathbf{0 . 0 6 9}$ & $\mathbf{0 . 3 9 8}$ \\
CCR1 & 0.633 & 0.063 & - & - \\
CXCR3 & 0.279 & 0.281 & 0.574 & 0.086 \\
S & 0.818 & 0.015 & $\mathbf{0 . 0 7 1}$ & $\mathbf{0 . 5 9 9}$
\end{tabular}

Simple regression analysis was performed comparing two variables (cell markers $v s$. fungi numbers and $v s$. MIP- $1 \alpha$ ). R square indicates the percentage of variation of variable $\mathrm{y}$ that is explained by variable $\mathrm{x}$. $* p$ values significant at level of $5 \%$; \# $p$ values significant at level of $10 \%$.

$\mathrm{CD}_{45 \mathrm{RO}^{+}}$in relation to $\mathrm{CD}^{+} 8^{+}$, we observed similar populations of these two cell types. Moreover, these authors also found an increased number of $\mathrm{CD}^{+}{ }^{+}$compared with $\mathrm{CD} 4^{+}$cells, while no difference between these cells were found in our study. This apparent discrepancy could be consequence of differences in the age and severity of the pathological process, and/or fungal infections, while there is significant variation in the evolution of cases and clinical presentation of lesions when comparing both studies. It must be taken in account that control samples even obtained from different anatomical sites than CR samples, could eventually explain the discrepancy found. Despite the differences found in CR lesions, patients with CR did not exhibit variation in the peripheral blood lymphocyte populations from control patients ${ }^{11}$. Additionally,

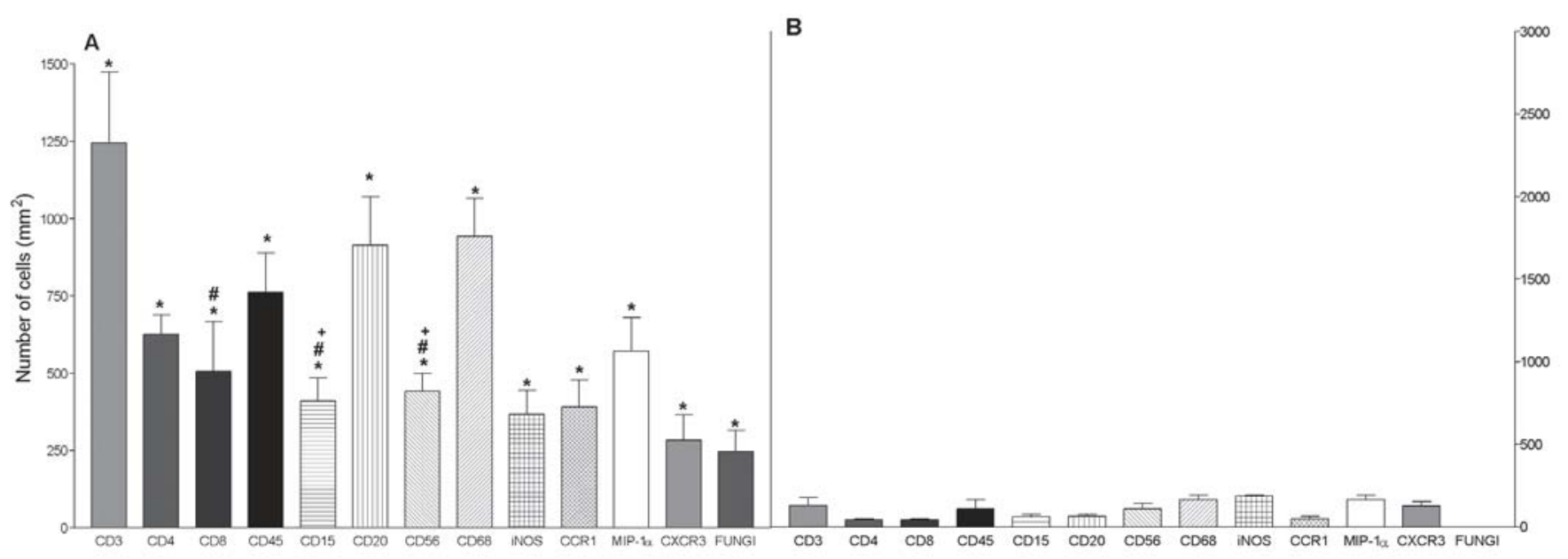

Fig. 2 - Number of lymphocytes (CD3, CD4, CD8, CD45RO, CD20 and CD56), neutrophils (CD15), macrophages (CD68), iNOS, CCR1, MIP-1 $\alpha$, CXCR3 and muriform cells per mm² in a representative lesion of chromoblastomycosis (A) and control healthy skin (B). Results represent mean \pm SEM of positive cells in five fields. *Indicates difference in relation to respective controls; ${ }^{+}$Indicates difference in relation to CD3, CD4 and CD20; "Indicates difference in relation to CD68. 
SÁ, V.C.; SILVA, T.A.; REIS, C.M.S.; CUNHA, F.Q.; FIGUEIREDO, F. \& BOCCA, A.L. - The pattern of immune cell infiltration in chromoblastomycosis: involvement of macrophage inflammatory protein-1 alpha/CCL3 and fungi persistence. Rev. Inst. Med. trop. S. Paulo, 49(1): 49-53, 2007.

we observed an increase in eosinophil count, which may act as effector cells in fungal infection?.

Our results suggest that MIP- $1 \alpha$ may participate in the host defense by attracting $\mathrm{CD} 45 \mathrm{RO}^{+}, \mathrm{CD}^{+} 8^{+}$and iNOS-producing cells; although it should be considered that these cells may be functioning as a source of MIP- $1 \alpha$ in CR. Indeed, most of the MIP- $1 \alpha$ expression was localized in mononuclear cells. Moreover, different cell sources, such as neutrophils, fibroblasts and epithelial cells may potentially account for chemokine production in CR. It has been shown that MIP- $1 \alpha$ has a critical role in the leukocyte infiltration in response to Aspergillus fumigatus $^{14}$ and cryptococcal Ags ${ }^{16}$.

With regard to chemokine receptors, we observed significant numbers of CCR1 and CXCR3-positive cells in relation to controls. Surprisingly, we did not observe any positive association between CCR1 and its ligand, MIP- $1 \alpha$. However, MIP- $1 \alpha$ could function as a ligand of another receptor, such as CCR5, or other chemokines may function as ligands for CCR1 $1^{17-18}$; thus, this relationship needs to be further explored in CR. In contrast, the expression of CXCR3 was found to be associated with MIP- $\alpha$, suggesting that this chemokine may be active in the recruitment of CXCR3-positive cells, as previously demonstrated ${ }^{25}$, or that even cells expressing CXCR3 act as a source of MIP- $\alpha$ in CR sites $^{13}$.

Our results also point to the involvement of fungus persistence in the continuous influx of cells to the site of infection, particularly activated and non-activated lymphocytes and iNOS positive cells. Similarly to others, we observed various muriform cells of the fungus in the lesions, both inside the cytoplasm of the macrophages and dispersed in the connective tissue, possibly suggesting phagocytes incompetence destroying the fungus ${ }^{26}$ that may be related to the degree of severity of cases included in our study (duration over 10 years). The persistence of Fonsecae pedrosoi in CR seems to be related to the inefficiency of the microbicidal mechanisms of the activated macrophages ${ }^{19}$. Furthermore, F. pedrosoi melanin inhibits fungi internalization ${ }^{8}$ and nitric oxide production by in vitro macrophages (unpublished results). Despite their association with fungal population, iNOS-positive cells showed a predominantly moderate expression associated with macrophage and multinucleated giant cells, even when fungi were observed inside these cells. On the other hand, expression of SOD, which converts superoxide radicals into less damaging hydrogen peroxide reactive oxygen intermediates, was intense in most cases and, in accordance with this finding, we observed an increase in the phagocytic ability and $\mathrm{H}_{2} \mathrm{O}_{2}$ production of Fonsecaea pedrosoi-infected macrophages (unpublished results). In fact, the activity of SOD enzyme has been shown to be increased following infection by intracellular pathogens ${ }^{12}$ and may indicate significant intracellular oxidant activity.

Although no defective humoral response has been observed in $\mathrm{CR}^{6,11}$, patients with $\mathrm{CR}$ have suppressed cellular immune responses to fungal antigens ${ }^{10}$. Furthermore, the cell-mediated immune response is a determinant of the CR clinical presentation, with the $\mathrm{T}$ cell proliferative response to chromoAg and levels of IFN- $\gamma$ progressively diminished and the increased IL-10 levels according to the severity of disease ${ }^{11}$. Taken together, these results can account for the moderate iNOS expression observed in our study, given that IFN- $\gamma$ and IL-10 have roles in stimulating and inhibiting iNOS production, respectively, by macrophages ${ }^{2}$. Therefore, it seems that the balance between the Tcell response and consequent macrophage activation may play a regulatory role in determining the outcome and fungal destruction in $\mathrm{CR}$ infections.

In conclusion:

- The fungal persistence seems to be associated with inefficient immune response that does not effectively destroy the fungus.

- The continuous antigenic stimuli, caused by fungal persistence, are probably a contributing factor to the progressive inflammatory cell infiltration in CR lesions.

- The chemokine MIP- $1 \alpha$ displays a role in the recruitment of effector cells and may be a potential target for augmentation of the antifungal activity and improvement of the outcome of the infection in CR.

\section{RESUMO}

\section{Padrão de infiltração de células do sistema imune na cromomicose: envolvimento de MIP-1 alfa da persistência fúngica}

A cromomicose é micose subcutânea crônica sistêmica caracterizada por resposta inflamatória crônica granulomatosa. No entanto, existem poucos dados a respeito do padrão de subtipos de leucócitos na cromomicose e sobre as vias envolvidas no recrutamento destas células. O objetivo deste trabalho foi avaliar os tipos celulares, bem como a expressão de quimiocinas, receptores de quimiocinas e enzimas em lesões de cromomicose. O infiltrado inflamatório foi caracterizado por meio de técnica imuno-histoquímica utilizando os seguintes marcadores CD68 (macrófagos), S100 (células de Langerhans), CD3, CD4, CD8, CD45RO, CD20 e CD56 (linfócitos) e CD15 (neutrófilos). A expressão de MIP- $1 \alpha$ (Proteína Inflamatória do Macrófago-1 $\alpha$ ), receptores de quimiocinas (CXCR3 e CCR1) e enzimas (superóxido dismutase-SOD e óxido nítrico sintase induzida-iNOS) foi avaliada pelo mesmo método. Observou-se um aumento de todas as populações celulares avaliadas em relação às amostras controle. As populações de células $\mathrm{CD} 15^{+}$e $\mathrm{CD} 56^{+}$foram significativamente menores que células $\mathrm{CD}^{+}, \mathrm{CD} 4^{+}, \mathrm{CD} 20^{+}$e $\mathrm{CD} 8^{+}$. A análise estatística revelou uma correlação positiva entre o número de fungos com as células CD3, CD45RO e iNOS-positivas. A expressão de MIP-1 $\alpha$ foi também associada às populações de células CD45RO, CD68, iNOS e CXCR3 positivas. Nossos resultados apontam para um possível papel de MIP- $1 \alpha$ e da persistência fúngica na infiltração de células inflamatórias nos sítios de cromomicose.

\section{ACKNOWLEDGMENTS}

We are grateful to Vivane Montanari Leal and Gleidson Alves Cardoso for technical assistance. This work was supported by a grant from Coordenação de Aperfeiçoamento de Pessoal de Nível Superior (Capes) and Conselho Nacional de Pesquisa (CNPq).

\section{REFERENCES}

1. BONECCHI, R.; BIANCHI, G.; BORDIGNON, P.P. et al. - Differential expression of chemokine receptors and chemotactic responsiveness of type $1 \mathrm{~T}$ helper cells (Th1s) and Th2s. J. exp. Med., 187: 129-134, 1998. 
SÁ, V.C.; SILVA, T.A.; REIS, C.M.S.; CUNHA, F.Q.; FIGUEIREDO, F. \& BOCCA, A.L. - The pattern of immune cell infiltration in chromoblastomycosis: involvement of macrophage inflammatory protein-1 alpha/CCL3 and fungi persistence. Rev. Inst. Med. trop. S. Paulo, 49(1): 49-53, 2007.

2. CUNHA, F.Q.; MONCADA, S. \& LIEW, F.Y. - Interleukin-10 (IL-10) inhibits the induction of nitric oxide synthase by interferon-gamma in murine macrophages. Biochem. biophys. Res. Commun., 182: 1155-1159, 1992.

3. D'AVILA, S.C.; PAGLIARI, C. \& DUARTE, M.I. - The cell-mediated immune reaction in the cutaneous lesion of chromoblastomycosis and their correlation with different clinical forms of the disease. Mycopathologia, 156: 51-60, 2002.

4. DE HOOG, G.S.; QUEIROZ-TELLES, F.; HAASE, G. et al. - Black fungi: clinical and pathogenic approaches. Med. Mycol., 38(suppl. 1): 243-250, 2000.

5. DIXON, D.M. \& POLAK-WYSS, A. - The medically important dematiaceous fungi and their identification. Mycoses, 34: 1-18, 1991.

6. ESTERRE, P.; JAHEVITRA, M. \& ANDRIANTSIMAHAVANDY, A. - Humoral immune response in chromoblastomycosis during and after therapy. Clin. Diagn. Lab. Immunol., 7: 497-500, 2000.

7. ESTERRE, P.; PEYROL, S.; SAINTE-MARIE, D.; PRADINAUD, R. \& GRIMAUD, J.A. - Granulomatous reaction and tissue remodelling in the cutaneous lesion of chromomycosis. Virchows Arch. path. anat., 422: 285-291, 1993.

8. FARBIARZ, S.R.; DE CARVALHO, T.U.; ALVIANO, C. \& DE SOUZA, W. - Inhibitory effect of melanin on the interaction of Fonsecaea pedrosoi with mammalian cells in vitro. J. med. vet. Mycol., 30: 265-273, 1992.

9. FELDMESSER, M.; CASADEVALL, A.; KRESS, Y.; SPIRA, G. \& ORLOFSKY, A. Eosinophil-Cryptococcus neoformans interactions in vivo and in vitro. Infect. Immun., 65: 1899-1907, 1997.

10. FUCHS, J. \& PECHER, S. - Partial suppression of cell mediated immunity in chromoblastomycosis. Mycopathologia (den Haag), 119: 73-76, 1992.

11. GIMENES, V.M.F.; SOUZA, M.G.; FERREIRA, K.S. et al. - Cytokines and lymphocyte proliferation in patients with different clinical forms of chromoblastomycosis. Microbes Infect., 7: 708-713, 2005.

12. HONG, J.E.; SANTUCCI, L.A.; TIAN, X. \& SILVERMAN, D.J. - Superoxide dismutasedependent, catalase-sensitive peroxides in human endothelial cells infected by Rickettsia rickettsii. Infect. Immun., 66: 1293-1298, 1998.

13. MAURER, M. \& VON STEBUT, E. - Macrophage inflammatory protein-1. Int. J. Biochem. Cell Biol., 36: 1882-1886, 2004.

14. MEHRAD, B.; MOORE, T.A. \& STANDIFORD, T.J. - Macrophage inflammatory protein-1 alpha is a critical mediator of host defense against invasive pulmonary aspergillosis in neutropenic hosts. J. Immunol., 165: 962-968, 2000.

15. OLIVEIRA, S.H.; LIRA, S.; MARTINEZ, A.C. et al. - Increased responsiveness of murine eosinophils to MIP-1beta (CCL4) and TCA-3 (CCL1) is mediated by their specific receptors, CCR5 and CCR8. J. Leuk. Biol., 71: 1019-1025, 2002.
16. OLSZEWSKI, M.A.; HUFFNAGLE, G.B.; MCDONALD, R.A. et al. - The role of macrophage inflammatory protein- 1 alpha/CCL3 in regulation of T cell-mediated immunity to Cryptococcus neoformans infection. J. Immunol., 165: 6429-6436, 2000

17. PROUDFOOT, A.E.; POWER, C.A.; ROMMEL, C. \& WELLS, T.N. - Strategies for chemokine antagonists as therapeutics. Semin. Immunol., 15: 57-65, 2003.

18. ROSSI, D. \& ZLOTNIK, A. - The biology of chemokines and their receptors. Ann. Rev. Immunol., 18: 217-242, 2000

19. ROZENTAL, S.; ALVIANO, C.S. \& DE SOUZA, W. - The in vitro susceptibility of Fonsecaea pedrosoi to activated macrophages. Mycopathologia (den Haag), 126: 85-91, 1994

20. SALLUSTO, F.; LANZAVECCHIA, A. \& MACKAY, C.R. - Chemokines and chemokine receptors in T-cell priming and Th1/Th2-mediated responses. Immunol. today, 19: 568-574, 1998.

21. SALLUSTO, F.; LENIG, D.; MACKAY, C.R. \& LANZAVECCHIA, A. - Flexible programs of chemokine receptor expression on human polarized $\mathrm{T}$ helper 1 and 2 lymphocytes. J. exp. Med., 187: 875-883, 1998.

22. SOTTO, M.N.; DE BRITO, T.; SILVA, A.M.; VIDAL, M. \& CASTRO, L.G. - Antigen distribution and antigen-presenting cells in skin biopsies of human chromoblastomycosis. J. cutan. Path., 31: 14-18, 2004.

23. SOUTO, J.T.; ALIBERTI, J.C.; CAMPANELLI, A.P. et al. - Chemokine production and leukocyte recruitment to the lungs of Paracoccidioides brasiliensis-infected mice is modulated by interferon-gamma. Amer. J. Path., 163: 583-590, 2003.

24. TAlHARI, S. \& NEVES, R.G. - Chromoblastomycosis. In: TRINDADE, J.F Dermatologia tropical. São Paulo, Médica \& Científica, 1995. p. 219.

25. TRIFILO, M.J.; BERGMANN, C.C.; KUZIEL, W.A. \& LANE, T.E. - CC chemokine ligand 3 (CCL3) regulates $\mathrm{CD} 8^{+}-\mathrm{T}$-cell effector function and migration following viral infection. J. Virol., 77: 4004-4014, 2003.

26. WALTER, P.; GARIN, Y. \& RICHARD-LENOBLE, D. - Chromoblastomycosis. A morphological investigation of the host-parasite interaction. Virchows Arch. A. path. Anat., 397: 203-214, 1982.

27. YANABA, K.; MUKAIDA, N.; MATSUSHIMA, K. et al. - Role of C-C chemokine receptors 1 and 5 and CCL3/macrophage inflammatory protein-1alpha in the cutaneous Arthus reaction: possible attenuation of their inhibitory effects by compensatory chemokine production. Europ. J. Immunol., 34: 3553-3561, 2004.

Received: 25 April 2006

Accepted: 2 August 2006 